\title{
NONLEGISLATIVE RULES AND THE ADMINISTRATIVE OPEN MIND
}

\author{
RONALD M. LEVIN*
}

\section{INTRODUCTION}

I have a great deal of admiration for Professor Robert A. Anthony's study of the binding effects of nonlegislative rules. ${ }^{1}$ His coinprehensive blend of case research, field investigation, and thoughtful advocacy certaiuly deserves careful consideration. I will not be surprised, however, if the Article ultimately provokes more arguments than it settles. The administrative law community has, after all, had a good deal of trouble reaching agreeinent about the interrelationships among legislative rules, interpretive rules, and general stateinents of policy. ${ }^{2}$ In the brief observations that follow, I have no hope of dissipating the "considerable sniog"3 that is frequently said to enshroud these terms; but perhaps this Comment can serve as a nodest step towards the "lowest achievable emission rate."

My main purpose liere is to discuss the "openmindedness" that agencies are required to nuamtain towards the positions that they announce in nonlegislative rules. I will offer a few observations about the circunistances in which this attitude is required, what agencies should do to maintain it, and how courts miglit pohice this obligation. Along the way, I will suggest that Anthony's expectations of openmindedness may be too high in the case of policy statenients, and not higli enough in the case of interpretive rules.

\section{Openmindedness and Policy Statements}

The logical starting point for an evaluation of Professor Anthony's Article is the familiar distinction between legislative and nonlegislative

* Associate Dean and Professor of Law, Washington University. This Colnment is based on remarks presented at a symposium on rulemaking held at Duke University School of Law on March 6, 1992.

1. Robert A. Anthony, Interpretive Rules, Policy Statements, Guidances, Manuals, and the Like-Should Federal Agencies Use Them to Bind the Public?, 41 Duke L.J. 1311 (1992).

2. For an insightful overview of the probleins of giving ineaning to these terms, see Michael Asimow, Nonlegislative Rulemaking and Regulatory Reform, 1985 DUKE L.J. 381, 383-401.

3. Noel v. Chapinan, 508 F.2d 1023, 1030 (2d Cir.), cert. denied, 423 U.S. 824 (1975), quoted in, e.g., Community Nutrition Inst. v. Young, 818 F.2d 943, 946 (D.C. Cir. 1987). 
rules. Briefly, legislative rules result from an agency's exercise of authority to make rules that have the force of law. ${ }^{4}$ The premise that legislative rules have "the force of law" has a number of ramifications, but the one that $I$ take as the theme of this Comment is the following: Legislative rules are binding on both private parties and the agency itself. In all administrative proceedings, the rule controls the admimistrator's conclusions on the issues it addresses, until such time as it is revoked, amended, or invalidated. A nonlegislative rule, on the other hand, is not binding: private parties are free to dispute the conclusions embedded in the rule, and the agency has an obligation to take such challenges seriously. ${ }^{5}$ As I will discuss, Anthony does not fully accept the general thesis that nonlegislative rules are nonbinding, but he does insist on the nonbinding nature of one species of nonlegislative rules: general statements of policy, known as "policy statements" for short.

The central problem with which Anthony concerns himself is that, m many instances, agencies give "practical binding effect" to policy statements that were not promulgated in a legislative fashion: officials refuse to consider parties' arguments, or at least behave in a manner indicating that they would refuse if anyone actually tried to persuade them to alter their views. The typical judicial response to such refusals (or threatened refusals) is to characterize the contested statements as legislative rules, and then to invalidate them for lack of notice-and-comment. Anthony regards these characterizations as analytically incorrect: in his view, statements that are not "issued legislatively" cannot "be" legislative rules, and the real question is whether the statements "should have been" promulgated as legislative rules. ${ }^{6}$ Nevertheless, he obviously endorses

4. See 2 Kenneth C. Davis, Administrative Law Treatise $\$ 7: 8$ (2d ed. 1979); 1 Charles H. Koch JR., Administrative LaW and Practice § 3.13, at 133 (1985); Asimow, supra note 2, at 383.

5. The "binding" quality of legislative rules that $I$ discuss in this Comment is a purely procedural concept, denoting preclusion of the right to be heard. This is the kind of binding effect that was at stake in the famous line of legislative ruleunaking cases running from United States v. Storer Broadcasting Co., 351 U.S. 192 (1956), through Heckler v. Campbell, 461 U.S. 458 (1983). Legislative rules are also sometimes said to differ from other rules by virtue of having the "force of law" in a substantive sense, i.e., by being "binding" on reviewing courts. See, e.g., $1 \mathrm{KoCH}$, supra note 4, $\S$ 3.52. That distinction plays an important role in administrative law, but must be approached with enormous care. One inust always bear in inind that even "legislative rules are subject to judicial review and often do not survive." Vietnam Veterans of Am. v. Secretary of the Navy, 843 F.2d 528, 537 (D.C. Cir. 1988). Conversely, even interpretive rules are entitled to some judicial deference, although not as much as legislative rules. See infra note 42 and accompanying text. In short, the differences between the standards of judicial review for legislative and nonlegislative rules are extraordinarily complex and elusive. However, these differences are not the focus of Anthony's Article, and I will touch on them only sporadically here.

6. See Anthony, supra note 1, at 1327. Although Anthony's proposed revision of the courts' diction holds a certain amount of appcal, it may raise its own difficulties, for it is not obvious how the Administrative Procedure Act (APA), 5 U.S.C. $\$ 551-559$ (1988), can be read as empowering 
the substance of these courts' holdimgs. Much of his Article documents, with evident approval, situations in which courts have condemned agencies for accordimg "practical bimding effect" to statements that had been issued without notice-and-comment procedure.7

Anthony recognizes, however, that policy statements play a legitimate role in the administrative process. ${ }^{8}$ In this connection, his basic contention is that if an agency intends to make use of such pronouncements, it must take care not to utilize them in a binding way. To this end, he suggests that if an agency decides to proceed nonlegislatively, it should, at the time of the policy statement's issuance, make an express declaration that the policy is tentative and subject to challenge later. Then, when the agency actually moves to apply the statement im a concrete case, it should affirmatively advise individuals that they have the right to challenge the pohicy. ${ }^{9}$

These prophylactic suggestions are constructive and helpful. There is, however, room for debate about how readily agencies should be faulted for failing to provide exphicit assurances of "openmindedness." Many have argued elsewhere that courts should be wary about holding that a purported policy stateinent is really a legislative rule, because such holdings might deter agencies from providing guidance about their thinking to the public-guidance that the public has a vital interest in receiving and that agencies should not always be expected to provide by legislative rule. ${ }^{10}$ The same reasoning counsels against asking agencies to bend over backwards to demonstrate their lack of commitment to the positions they set forth in policy statements. If we want to encourage agencies to provide guidance, we should not be too quick to criticize them for statimg their views with confidence. ${ }^{11}$ Moreover, when an agency does choose to issue a statement of "tentativeness," the agency

courts to hold that a policy statement "should have been" issued as a legislative rule. Perhaps the traditional usage is preferable-saying that an invalid legislative rule "is" a legislative rule may be no more incongruous than saying, as we often do, that an unconstitutional statute "is" a statute, or that an adjudicative order issued without a required hearing "is" an order.

7. See Anthony, supra note 1, at 1333-51.

8. See id. at 1317.

9. See id. at 1374.

10. See, e.g., KoCH, supra note 4, § 3.26; Asimow, supra note 2, at 386-88, 402-09; Peter L. Strauss, The Rulemaking Continuum, 41 DukE L.J. 1463 (1992). Legislative rules are not only increasingly difficult to adopt, see Thomas O. McGarity, Some Thoughts on "Deossifying" the Rulemaking Process, 41 DUKE L.J. 1385 (1992), but also are difficult to modify if an agency later discovers them to be flawed.

11. Cf. Association of Nat'l Advertisers, Inc. v. FTC, 627 F.2d 1151, 1170 (D.C. Cir. 1979) (holding that a rulemaking official should not be disqualified for bias absent "a clear and convincing showing that the agency member has an unalterably closed mind on matters critieal to the disposition of the proceeding") (emphasis added), cert. denied, 447 U.S. 921 (1980). 
should not be expected to say that it currently has doubts about its position (a claim that, if routinely recited, would soon lose credibility anyway). A simple statement that the public has the right to offer opposing views should usually suffice to inform the public of its right to contest a policy-assuming that some disclaimer is deemed necessary at all.12

Like it or not, we must accept the reality that agencies will not always go out of their way to invite the public to challenge their informally adopted policies. Thus, in many, or perhaps most, cases, the only way we will be able to decide whether or not an agency was "openininded" will be to observe, retrospectively, how the agency responded when people did attack the statement. According to the leading judicial opinion on pohicy statements, Pacific Gas \& Electric Co. v. Federal Power Commission, 13 the agency must "be prepared to support the policy just as if the policy statement had never been issued."14 That formula is more than a hittle vague, and a brief exegesis of its practical implications may be useful here.

The essence of the agency's duty, I suggest, should be an obligation, first, to allow the challenger to present a case, and second, to respond meaningfully to that case. One aspect of this duty was recognized in the very recent case of Bechtel v. FCC. ${ }^{15}$ In Bechtel, an applicant for a broadcast hicense argued that the FCC's practice of favoring prospective owner-managers over owners who planned to hire inanagers, as prescribed im a 1965 pohicy statement, was obsolete. The Commission brusquely declined to examine this claim. On appeal, the D.C. Circuit ordered the Commission to reexamine the imtegration criteria. Following Pacific Gas, the court held that the agency's desire to adhere to established policy was not a valid justification for refusing to consider the applicant's claiin; rather, the agency was required to respond to the apphicant's showing that changed legal and factual circumstances cast

12. The kind of notification that Anthony seems to have in mind would serve only to advise the public of something that it could have known anyway: because the policy statement was not issued legislatively, the agency could not lawfully accord it bimding effect. Anthony argues that agencies should be solicitous of relatively mexperienced attorneys who may not be aware of their right to challenge unless it is called to their attention. See Anthony, supra note 1, at 1372. Yet even he does not suggest that courts shonld often strike down a rule because of an agency's failure to provide such assistance. $C f$. Atkins v. Parker, 472 U.S. 115, 130-31 (1985) (presumption that citizens know the law limits due process rights).

13. 506 F.2d 33 (D.C. Cir. 1974).

14. Id. at 38.

15. 957 F.2d 873 (D.C. Cir. 1992), petition for cert. filed, 60 U.S.L.W. 3783 (U.S. Apr. 30, 1992) (No. 91-1744). 
doubt on the assumptions that had led the Commission to adopt the policy originally. ${ }^{16}$

Yet Pacific Gas has not been read to mean that administrators must literally reconsider all the issues underlying a policy statement whenever it is implicated in subsequent cases. To the extent that the statement contains adequate answers to the challenger's contentions, the agency certainly may consnlt it and cite to it, so long as the agency also gives full attention to any issues raised for the first time in the current proceeding. ${ }^{17}$ The caselaw also suggests another common-sense limitation: the agency has no duty to respond unless the challenger's contentions are clearly articulated ${ }^{18}$ and satisfy a "threshold requirement of materiality." 19

The caselaw defining agencies' obligations im dealing witl policies developed during adjudication offers further guidance in determining the kind of "openmindedness" an agency must display when it has issued a policy statement. Although Anthony devotes only fleeting attention to this body of law, ${ }^{20}$ the procedural questions that arise in these cases are directly analogous to those under discussion here. ${ }^{21}$ In the adjudication cases, courts have been extraordinarily hesitant to fanlt agencies for not utilizing the legislative rulemaking process; 22 but they have held that the 1985).

16. Id. at 880-81. For a similar holding, see Simmons v. ICC, 757 F.2d 296, 300 (D.C. Cir.

17. Independent Petroleum Ass'n of Am. v. Economic Regulatory Admin., 870 F.2d 168, 172 (5th Cir. 1989); Panhandle Producers \& Royalty Owners Ass'n v. Economic Regulatory Admin., 847 F.2d 1168, 1175 (5th Cir. 1988); Panhandle Producers \& Royalty Owners Ass'n v. Economic Regulatory Admin., 822 F.2d 1105, 1110-11 (D.C. Cir. 1987); cf. Baltimore Gas \& Elec. Co. v. United States, 817 F.2d 108, 115-16 (D.C. Cir. 1987) (condoning the ICC's failure to respond to comments during rulemaking proceeding, because it had fully responded during prior adjudications).

18. See, e.g., Vermont Yankee Nuclear Power Corp. v. Natural Resources Defense Council, Inc., 435 U.S. 519, 553-54 (1978); Northside Sanitary Landfill, Inc. v. Thomas, 849 F.2d 1516, 151921 (D.C. Cir. 1988), cert. denied, 489 U.S. 1078 (1989).

19. See, e.g., Portland Cement Ass'n v. Ruckelshaus, 486 F.2d 375, 394-95 (D.C. Cir. 1973) (discussing when an agency must respond to comments offered during rulemaking proceeding), cert. denied, 417 U.S. 921 (1974); see also Building \& Constr. Trades Dep't, AFL-CIO v. Brock, 838 F.2d 1258, 1271 (D.C. Cir. 1988) (holding that OSHA need not produce substantial evidence to resist every proposed change in its rules, however minor).

20. See Anthony, supra note 1, at 1312 n.2, 1330, 1351 n.245, 1356 n.272.

21. The following discussion draws heavily on the analysis in Richard K. Berg, Re-Examining Policy Procedures: The Choice Between Rulemaking and Adjudication, 38 ADMIN. L. REv. 149 (1986). Berg's excellent report formed the basis for a resolution by the ABA House of Delegates that highlights the similarity between the duty of openmindedness that agencies owe towards the principles developed in policy statements, on the one hand, and in adjudicative decisions, on the other. According to the resolution, "[w] here the precedent of a prior adjudication is sought to be applied in a subsequent adjudication, a party should have a meaningful opportunity to persuade the agency that the principle involved should be modified or held inapplicable to his situation." Id. at 177 (quoting resolution).

22. See, e.g., NLRB v. Bell Aerospace Co., 416 U.S. 267, 294 (1974). 
precedents inade in adjudication may not be treated as conclusive when parties raise challenges to the principles announced there. ${ }^{23}$ In practice this has meant that an agency risks reversal if, for example, it lacks evidentiary support for a critical premise of its caselaw "rule" 24 or brushes aside significant distinctions between its precedents and the case before it. ${ }^{25}$

In soine of these decisions, courts apparently have assumed that an agency may rely on the record coinpiled in an earlier case as a source of factual support for a caselaw "rule."26 By analogy, these decisions suggest that when a private party challenges a policy statement during subsequent dealings with an agency, the agency inay similarly rely on facts that it gathered while developing the pohcy statement. Indeed, the natural reference point froin which to assess the rationality of the agency's exercise of discretion is the administrative record that was before it when it actually exercised that discretion.

Decisions applying the doctrine of official notice also support the practice of relying on facts gathered while developing a policy stateinent. ${ }^{27}$ Just as in the official notice context, however, the approach can work only if the agency devises an effective way to furnish the prior administrative record to the challenger, so that the latter has an adequate "opportunity to show the contrary."28 Agencies, courts, and counsel will have to coine to grips with practical issues of this kind if the notion of an "administrative open mind" is to maintain its vitality.

23. See NLRB v. Wyman-Gordon Co., 394 U.S. 759, 766 (1969) (plurality opinion) (denying that "policies announced in adjudication are 'rules' in the sense that they must, without more, be obeyed by the affected public").

24. See Shell Oil Co. v. FERC, 707 F.2d 230, 235 (5th Cir. 1983) (agency's assumption about gas producer's costs, which was derived from prior case, did not rest on substantial evidence); NLRB v. St. Francis Hosp. of Lynwood, 601 F.2d 404, 414-16 (9th Cir. 1979) (evidence compiled in NLRB decision prescribing bargaining unit for one lospital was insufficient to support findings as to conditions in second hospital in later case).

25. See Jersey Cent. Power \& Light Co. v. FERC, 810 F.2d 1168, 1184 (D.C. Cir. 1987) (en banc) (FERC overlooked major differences between instant case and precedent on which it souglit to rely); see also Berg, supra note 21, at 174-75 (contending that an agency must allow parties in adjudication to argue that caselaw precedent should not be applied to them).

26. See Shell Oil, 707 F.2d at 235 (stating that "tlie Commission has adduced no evidence, either here or in Mullins \& Prichard [tlie prior decision], to sliow that this 'fact' is indeed a fact"); St. Francis, 601 F.2d at 416 n.14 (statiug that reliance on a previous detcrmination is appropriate where reliance is based on adequately documented facts).

27. See United States v. Pierce Auto Freight Lines, 327 U.S. 515, 527-28 (1946) (allowing an agency to take official notice of the record from a prior proceeding); Railroad Comm'n of Texas v. United States, 765 F.2d 221, 229 (D.C. Cir. 1985) (same).

28. 5 U.S.C. §556(e) (1988); see also St. Francis, 601 F.2d at 416 (stating that "certain [caselaw] presumptions inay be employed by the Board so long as interested parties are given the opportunity to effectively present evidence to rebut the presumptions"). 


\section{OPENMINDEDNESS AND INTERPRETIVE RULES}

In sharp contrast to his insistence that policy statements must be tentative both on their face and in practice, Professor Anthony maintains that interpretive rules need not be tentative at all, and that agencies may "relentlessly" deny private parties an opportunity to take issue with them at the administrative level. ${ }^{29}$ Although, in his view, interpretive rules are not "legally binding" (courts are free to overturn them on the merits, or at least are freer than in the case of legislative rules), an agency may make them "binding as a practical matter" by choosing to ignore argnments that the interpretation is mistaken. ${ }^{30}$ Given the populist tone of most of his Article, the assertion is more than a little surprising.

Anthony points to no one besides himself who has ever exphicitly endorsed this broad thesis. Moreover, one can find suggestions in the literature that otliers might take a different view. ${ }^{31}$ Nevertheless, it is true that most previous analyses of the tentative nature of nonlegislative rules have focused on pohicy statements, not interpretive rules. Until now, the question of whether agencies must be "openminded" about their interpretive rules seeins not to have been seriously explored in the literature. Now that Anthony has raised the question so frontally, an additional perspective on the matter seeins to be in order.

In my view, the proper distinction to be drawn here is between legislative rules, which have tlie force of law and must be followed until rescinded or struck down, and nonlegislative rules (whether policy statements or interpretive rules), which express an agency's current views but do not prevent private persons from attempting to persuade it to alter

29. Anthony, supra note 1, at 1361 ; see id. at 1314,1340 .

30. See id. at $1314 \&$ n.6.

31. See, e.g., Vietnam Veterans of Am. v. Secretary of the Navy, 843 F.2d 528, 537-38 (D.C. Cir. 1988) ("[T]he agency remains free in any particular case to diverge from whatever outcome the policy statement or interpretive rule might suggest. ... In such a case, any affected private party is free to appeal to the agency for such a divergent result."); $1 \mathrm{KocH}$, supra note $4, \S 3.73$ at 192 ("Where the individual did not rely on [a] nonlegislative rule to his detriment, the agency should look to such rules for guidance and not apply them where mappropriate as if they had general binding effect."). Other thoughtful students of the field have remarked that interpretive rules are "not legally binding" or "not binding on anyone," without indicating that they were referring exclusively to the substantive consequences of such rules. See, e.g., National Latino Media Coalition v. FCC, 816 F.2d 785, 788 (D.C. Cir. 1987) (Bork, J.); Asimow, supra note 2, at 383, 385.

The Supreme Court has at times noted that an agency's failure to adhere to its interpretive rule renders its revised view less worthy of deference. See, e.g., EEOC v. Arabian Am. Oil Co., 111 S. Ct. 1227,1235 (1991) (refusing to defer to the EEOC because of its previous contrary interpretations of the statute in question); United Hous. Found., Inc. v. Forman, 421 U.S. 837, 858 n.25 (1975) (refusing to accept the SEC's view of securities laws at issue because it was inconsistent with the Coinmission's earlier interpretation). These holdings obviously imply that an agency is not bound by an interpretive rule. If not, it is difficult to accept the notion that the public could be. 
those views. Quite apart from their substantive effects, therefore, interpretive rules are nonbinding in a procedural sense: they cannot cut off the right of private parties to be heard in adininistrative proceedings.

What has led Anthony to take his uncharacteristic, if not uncomfortable, position? Essentially, he rehes on the reasoning that various courts have used to explain the exemption in the Administrative Procedure Act (APA) for interpretive rules:32 with such rules the agency "is not inaking new law or changing the law but is inerely clarifying or explaining preexisting law." 33 It would seem, however, that he has read too much into this proposition. The cases have used this theory to explam why Congress did not confer a right to be heard at the time of a rule's proinulgation. ${ }^{34}$ I would understand these cases to inean that, because an interpretive rule is only an expression of advice, public input on its contents can safely be postponed until subsequent proceedings. To transform this theory into a rationale by which the agency may deny a challenger's right to be heard at any time-indeed, may extinguish any right to be heard that the challenger previously enjoyed ${ }^{35}$-is a very large juinp, and Anthony neither offers nor cites to any real justification for that expansion. ${ }^{36}$

Anthony's thesis would be more appealing if it were possible to argue that input froin the public serves no purpose when an agency is merely seeking to "clarify or explain the law." But who could believe that? Notwithstanding the quaint fiction that an interpretive rule merely "reminds" citizens of their legal obligations, ${ }^{37}$ it is obvious that the task of ascribing ineaning to the coinplex and confusing mandates that Congress lias entrusted to the agencies is a distinctly creative process. The discipline of having to respond to the perspectives of interested private

32. 5 U.S.C. $\S 553(b)(A)(1988)$.

33. Anthony, supra note 1, at 1355 n.270; see id. at 1313, 1325, 1376.

34. See, eg., American Hosp. Ass'n v. Bowen, 834 F.2d 1037, 1045-46 (D.C. Cir. 1987).

35. Depending on the circuinstances, persons who are threatened with adverse administrative action can coinmonly assert a right to be heard on the basis of statutes, regulations, or the Due Process Clause. When the question at issue is legal rather than factual, the nature of the right to be heard inay well be limited, see, e.g., FCC v. WJR, 337 U.S. 265, 274-77 (1949) (rejecting any universal right to oral argument on issues of law), but there seems no reason to doubt that an opportunity to be heard in some fashion must still be afforded, see Goldberg v. Kelly, 397 U.S. 254, 267-68 \& n.15 (1970) (suggesting that where there are no factual issues in dispute or where the application of a rule of law is not intertwined with factual issues, due process may require "only" an opportunity for written subınission).

36. He does note that Congress wished to allow agencies to issue interpretive rules " 'without having to undertake cumbersolne proceedings,' " Anthony, supra note 1, at 1313 n.5 (quoting American Hosp. Ass'n, 834 F.2d at 1045), and that the agency needs to "get on with [its] job," id. at 1375. In no way do these points distinguish interpretive rules from policy statenents, which likewise may be issued without public proceedings but do not thereby becoine binding on meinbers of the public.

37. Citizens to Save Spencer County v. EPA, 600 F.2d 844, 876 n.153 (D.C. Cir. 1979). 
parties is bound to enhance the quality of the legal interpretations that agencies adopt. Further, an agency's willingness to listen and respond to parties' arguments should bolster the legitimacy of its ultimate stances. Of course, Anthony is well aware of these poimts. They underlie his proposal that agencies should use notice-and-comment procedure voluntarily when issuing significant interpretive rules. ${ }^{38}$ Regardless of whether agencies follow that suggestion, they surely liave an obligation to histen and respond to criticisins of their imterpretations at some stage in the administrative process. Adoption of Anthony's analysis would release them from that obligation.

Anotlier argument traditionally made in support of the APA exemption is that public participation in agencies' creation of interpretive rules is unnecessary because such rules are subject to plenary judicial review. Congress seems to have been motivated in part by this consideration when it created the exemption. ${ }^{39}$ One must doubt, however, that this rationale can carry enough weight to support the conclusion that an agency can legitiniately ignore the public's views both when it promulgates an interpretive rule and afterwards. In the first place, numerous administrative proceedimgs are never appealed to the courts. Second, judicial review of an interpretive rule does entail some degree of deference, albeit not as much as in the case of a legislative rule. ${ }^{40}$ For both reasons, the opportunity to inake one's case at the agency level is vital.

Finally, if it were generally agreed that interpretive rules may be used in a binding way and policy statements may not, agencies would need to be able to tell thein apart, a task tliat they would find quite daunting. Trying to distinguish interpretive rules from policy statements is as difficult as trying to separate legal issues from discretionary issues (or perliaps those are two facets of the very same enigma). After all, when agencies formulate their positions, they typically are botli elaborating on a statute and engaging in policy choice. They inay not pause to ask thenıselves where one activity leaves off and the otler begins; in their

38. See Anthony, supra note 1, at 1373-74; see also Administrative Conference of the United States, Recommendation No. 76-5, Interpretive Rules of General Applicability and Statements of General Policy, 1 C.F.R. § 305.76-5 (1991) (calling for public participation in the promulgation of interpretive rules and general statements of policy that are "likely to have a substantial impact on the public").

39. See S. Doc. No. 248 , 79th Cong., 2d Sess. 18 (1946).

40. See, e.g., Davis v. United States, 495 U.S. 472, 484 (1990) ("Although the Service's interpretive rulings do not have the force and effect of regulations, ... we give an agency's interpretations and practices considerable weight where they involve the contemporaneous construction of a statute and where they have been in long use"); Skidmore v. Swift \& Co., 323 U.S. 134, 140 (1944) (interpretive rules can have "power to persuade, if lacking power to control"); Robert A. Anthony, Which Agency Interpretations Should Bind Citizens and the Courts?, 7 YALE J. ON REg. 1 (1990). 
minds, there may be no difference. ${ }^{41}$ The objection here is not merely that the line is hard to draw, but that there are no persuasive functional guideposts that can help agencies draw it. To the extent that the law subscribes to Anthony's position, an agency that wants to know whether it must offer regulated persons a right to challenge a nonlegislative statement is virtually compelled to speculate about whether the courts would ultimately uphold the agency's view of the meaning of the underlying statute. The solution I am proposing is simpler: If an agency wishes to adopt a definitive position, it can use legislative rulemaking; if it elects not to issue a legislative rule, it should remain willing to entertain challenges to the substance of the statement, whether on legal grounds or policy grounds. ${ }^{42}$

If anything, an agency's obligation to remain "openıninded" as it implements an interpretive rule should generally be less burdensome to the agency than if a policy statement were involved. The reasons are pragmatic, not conceptual. When purely legal questions are at issue, the parties normally should only need to submit briefs, not build a record. ${ }^{43}$ Furthermore, legal issues by their nature tend to revolve around a linnited body of data (the statute, legislative history, etc.). Once the agency has thoroughly analyzed that data in an interpretive rule, it need not keep repeating itself; in responses to challenges to the rule, the agency can

41. Moreover, a single pronouncennent can easily contain both interpretive and discretionary elements. See 2 Davis, supra note 4, § 7.5, at 25.

42. Under the current easelaw, courts attempting to distinguish legislative from interpretive rules often attempt to decide whether a statement attempts to interpret existing language or, instead, adds meaning to the statute. See, e.g., United Technologies Corp. v. EPA, 821 F.2d 714, 719-20 (D.C. Cir. 1987); General Motors Corp. v. Ruckelshaus, 742 F.2d 1561, 1565 (D.C. Cir. 1984) (en banc), cert. denied, 471 U.S. 1074 (1985). Given the intinate connection between interpretation and policymaking in the administrative process, courts making this distinction can easily reach unsatisfying, perhaps unprincipled, results. See Asimow, supra note 2, at 384, 394-97; see also McLouth Steel Prods. Corp. v. Thomas, 838 F.2d 1317, 1322 n.3 (D.C. Cir. 1988) (distinction is "far from selfapplying"). Indeed, as Anthony recognizes, legislative rules are frequently used to "interpret." Anthony, supra note 1, at 1325 n.64. Under this approach, moreover, the procedural question of whether the rule is interpretive is difficult, if not inpossible, to separate from the substantive question of whether the interpretation is correct.

The diseussion in text suggests that courts should consider an alternative to the prevailing anal. ysis. They might think of the APA exemption for "interpretative rules [and] general statements of policy," 5 U.S.C. $\$ 553(\mathrm{~b})(\mathrm{A})(1988)$, as contemplating a single category, i.e., nonlegislative rules. (The two statutory terns would be secn as endpoints on a spectrum, but nothing would turn on whether a given rule was closer to one end of the spectrum than the other.) If the agency were willing to commit itself to openmindedness, its rule could be held to fall within the exeinption; if it wanted binding effect, the rule would fall outside. This reconsideration of precedent will surely not occur overnight, but it might point the way towards a certain degrce of "sinog" control. One can read Community Nutrition Inst. v. Young, 818 F.2d 943 (D.C. Cir. 1987), as having adopted this analysis already.

43. See Mackey v. Montrym, 443 U.S. 1, 15 n.8 (1979) (deeuning evidentiary hearing on historical facts to be ill-suited to resolution of question of law). 
simply cite the rule's original analysis. A challenger who raises new arguments, however, deserves a fuller response, and the administrator's failure to address such contentions may bode ill for the agency in the event of judicial review. ${ }^{44}$

\section{CoNCLUSION}

My analysis can be summarized in a few simple propositions. When an agency undertakes to communicate with the public by rule, but does not utilize its power to act with the force of law, the resulting rule might be characterized as either an interpretive rule or a general statement of pohicy, or possibly both. Which label the agency uses should have hittle effect on the pubhic's right to be heard, because roughly the same procedural requirement comes into play either way. That requirement consists in a duty to give fair consideration to challenges that private parties subsequently raise agamst the determinations contained in the rule. In the wake of Professor Anthony's valuable study, the question of what constitutes fair consideration deserves continunig attention.

44. See Skidmore, 323 U.S. at 140 (deference to interpretive regulation depends in part on "the thoroughness evident in its consideration"); SEC v. Sloan, 436 U.S. 103, 117-18 (1978) (following Skidmore and holding that unexplicated agency position deserves little deference). 